\title{
TEAMWORK IN MANUFACTURING ENTERPRISE PERFORMANCE ACHIEVEMENT
}

\author{
Inese Lusena-Ezera ${ }^{1}$, Diana Liduma ${ }^{2}$ \\ ${ }^{1}$ Faculty of Management and Social Sciences, Liepaja University, Liela str. 14, Liepaja, Latvia \\ ${ }^{2}$ Institute of Management Science, Liepaja University, Liela str. 14, Liepaja, Latvia \\ E-mails. ${ }^{1}$ inese.lusena-ezera@liepu.lv(correspondingauthor); ${ }^{2}$ diana_liduma@inbox.lv
}

\begin{abstract}
Even though various work organization forms and instruments exist for efficient manufacturing process and economic efficiency achievement in manufacturing enterprises, the issue is still topical which of the factors in production management - human resources or technologies is the main impellent in performance achievement in manufacturing enterprises. Research aim is to find out whether approach based on teamwork is applied in performance achievement. Different level managers of eight manufacturing enterprises (total 21 managers) from Liepaja City (Latvia) and suburban area were questioned. Research results prove that in manufacturing enterprise performance characteristics of teamwork can be noticed in general. However, size of manufacturing enterprise (number of employees) is the determinant factor to whether employees' strive for a common goal and believe in teamwork in general.
\end{abstract}

Keywords: characteristics of teamwork, labour productivity, manufacturing enterprise, organization of work.

JEL Classification: D23, M10.

\section{Introduction}

The data of the Ministry of Economics of Latvia Republic confirm that labour productivity in manufacturing industry is only $35 \%$ of the EU28 average (National Industrial Policy Guidelines 2012-2020). It shows that the low labour productivity and the issue of work efficiency increase on managers' agenda of the Latvia manufacturing companies during the recent decades still highlights the topical problem to be solved, thus the managers of the particular area have to look for and implement into practice other or possibly new approaches for work performance promotion, encouraging managers to choose - either to rely on technical and technological factors or the human resource factor for the company's performance achievement, or - to be flexible and in management of companies and production processes focus on the interactions of the above mentioned factors. Envisaging the necessity for a flexible approach in manufacturing such changes in companies mean development in structures of horizontal character and a more direct management contact with employees in a wide range of manifestations, including statement of company's goals and work performance priorities, effective personnel management
(Raudeliūnienė \& Meidute, 2014; Merkevičius, Davidavičienè, Raudeliūnienè, \& Buleca, 2015) in whose achievement just the teamwork approach plays a crucial role. For instance, according to Harrington-MacKin (1994) in the 70s-90s teamwork has been appreciated in such big engineering industry companies as General Motors, Saab and Volvo, also Toyota. General Motors revealed that the manufacturing organization based on teamwork in the production line operation resulted in a much higher product quality without increasing the time consumed in the production process. In its turn, Saab and Volvo, starting their new factories, employed different teams of assembly workers, which allowed to decrease the total costs for $25 \%$. Also in the Millennium Century Studies a positive teamwork relation to the company's productivity has been revealed (Hamilton, Nickerson, \& Owan, 2003; Boning, Ichniowski, \& Shaw, 2007). In the course of development the efficiency of teamwork application, achieving higher performance both in terms of time, cost and quality, has been noticed in worldwide companies.

Within this article the literature review is based on the exposition of mutual interactions of 
labour productivity and teamwork in manufacturing companies emphasizing mostly the significance of teamwork in the company's performance achievement. In its turn, the practical point of view in Liepāja City and its surrounding companies provides an insight in the situation both in priorities which have been set as achievable outcomes by the company managers and in the fact whether the company's action has been directed towards formation of such work environment in which the elements characteristic to teamwork can been seen.

\section{Literature review}

Implementing the manufacturing function for the material value creation and applying different tools promoting interactions of workforce and manufacturing factors, it is important for a manufacturing company to obtain rational application of manufacturing resources and achieve economic efficiency, which can be related to both the organizational work and one of its resources or individual processes. According to Keniņš Kings et al. (2002) labour productivity can only be increased with constant and continuous work. Moreover, it cannot be done in a short period of time. The significance of efficiency measuring as well as manufacturing factors change. Regarding the assessment of the company's performance - the traditional indices are supplemented by other ones, where the conventional common work performance assessment systems are replaced by the systems which provide a perspective aspect of the further activity, linking the indices with the companies' strategic future solutions (Dāvidsone, 2008; Harvard Business Review on, 2008a). Due to the variety of labour productivity influencing factors in the company - from technical and technological solutions to economic, organizational and social measures (Zvirbule-Bērziña, Mihejeva, \& Auzinna, 2004), the interconnection of labour productivity with the teamwork as an important tool for the change of management structures and approaches in the modern companies is being looked for.

The operation scale of big companies often requires a vertical organizational structure with a bureaucratic administrative control system. However, the horizontal environment requires from the manager support provision for employees, more focus on attention to tasks, management delegation, delegating more to the lower management level (Ķeniņš Kings et al., 2002) and taking on new roles, performing simultaneously the roles of a manager, leader and couch (West, 2004). The "trapezium form" is offered in such environment creation as an efficient solution by Belbins (2009), simultaneously forming both management and work teams which according to Christopher Meyer (Harvard Business Review on, 2008b) means the change of conventional performance assessment systems, giving autonomy not only to team activities, but also authorization to teams to set indices for their work performances.

Explaining historical development of teamwork in industrial manufacturing companies, West (2004) has already pointed at Henry Ford's attempts to apply a flexible approach in the mass production process and adoption of Japanese methods in work organization of European and US companies, where just work in teams was applied to reduce the hierarchic management approach in mass production after the World War II. In its turn, within the research carried out by Flores-Fillol, Iranzo, and Mane (2017) on mutual relations between teamwork and organizational structure of companies, it has been concluded that delegation of joint decision making is positively related to teamwork. However, separating delegation of companies' strategic decisions from production decisions, it has been discovered that just delegation of strategic decisions in companies is teamwork promoting. According to Flores-Fillol et al. (2017) it means that also teamwork in a company is able to function under the impact of certain processes or implemented activities.

Even though the relation between teamwork and labour productivity is revealed in the very explanation of the term "team," emphasising simultaneously the necessity for both a common goal, cooperation, communication, mutual trust, various and equally mutual complementary competences among participants, and promotion of autonomy and significance of the manager- leader's role in work groups (Harrington-MacKin, 1994; Maginn, 1994; West, 2004, 2012; Belbins, 2009; Katzenbach \& Smith, 2015; Haas \& Mortensen, 2016) the term teamwork also has to be related to tangible company performance outcomes. Research outcomes on tangible benefits and role of teamwork in labour productivity increase in manufacturing companies have been mentioned by Harrington-MacKin (1994) more than 30 years ago, revealing just the relation between the human factor (self-respect and recognition) (Mayo, 1933) and work organization in teams with productivity (Lawler, 1986; Hoerr, 1987; S. M. Herman \& M. O. Herman, 1989; Dumaine, 1989; Sheridan, 1990), thus also confirming Drucker's 
(Harvard Business Review on, 2008b) opinion that in the company's welfare formation it is necessary to divide the human resources as purposefully and thoughtfully as financial resources. Also in the quite recent studies approval has been obtained that teamwork in production is one of the most widely used organisational innovation concepts in Slovenian manufacturing companies (Palčic, Buchmeister, \& Polajnar, 2010), in its turn the research of 1,298 manufacturing firms located in Germany has found out the positive relationship among flexibility, complexity, new products, organizational concepts, and teamwork implementation in production (Bikfalvi, 2011). As Barets (2008) has written, more and more company managers have asked themselves in the whole world about the most essential factor in corporate integrity, in the ability to implement the mission and opportunities to enhance the company performance, thus understanding that still employees are the most important value of every company. Therefore the team formation reason is not only the issue of profit and innovations, but also an important issue of "health" or well-being (West, 2004). The expert of Latvia national economy Karnite (2012) thinks that the employee's labour productivity depends on the conditions in which the person has to work, in addition to the significance of a fair and honest attitude towards the payment and provision of social guarantees to promote the employees' loyalty. However, at the same time one may not forget about the employee's role in work quality assurance: the employee's individual characteristics, skills, the will to work and satisfaction with the work performance (Karnīte, 2012).

The above facts make us conclude that just the company manager has to create appropriate opportunities for teamwork approach implementation in the company, including in it not only the increase of the company's organizational efficiency, but also the manager's abilities and readiness to implement teamwork in the entire company in general. It can equally mean changes in the existing work organization and organizational structure. According to Faisal, Abdelghafour, and Sukina (2012), it is also one of the manager's biggest challenges. Irrefutably, peculiarities of the manufacturing process and its relation to the basic principles of workforce and capital planning also have to be understood in formation of a successfully functioning and competitive manufacturing company (Zvirbule-Bērziña et al., 2004). However, in the context of teamwork managers have to be aware that alongside the introduction of teamwork philosophy in the company, the culture mechanism of the company also has to be introduced on all levels of the business activity.

\section{Research methodology and respondents}

The methodology implemented for Case Study involves an analysis of eight (8) manufacturing enterprises from Liepaja City and suburban area, surveying twenty one (21) managers of different management levels from manufacturing companies with an aim to find out whether the approach based on teamwork is applied in performance achievement in Liepaja City and suburban area manufacturing enterprises. For manufacturing enterprise selection from Liepaja City and suburban area the nonprobability sampling method - convenience method was used. The study was carried out from December 2017 to January 2018. To achieve the goal of this study, an online questionnaire was worked out to clarify:

- whether the employees' labour productity is measured in the manufacturing companies and what activities have been implemented in the companies recently for the labour productivity growth;

- what kind of work environment - vertical/horizontal is implemented in the manufacturing enterprises;

- what teamwork features can be noticed in the manufacturing company management and what, according to the managers' opinion, determines work performance in the companies of this kind.

Microsoft Excel application was used to process the quantitative data of the research.

For information provision on the profile of the chosen manufacturing companies and comparative analysis performance, in the survey there were included questions (both in nominal and ordinal scale) about the size of the manufacturing company, market scale and main activity type, as well as the management level to which the surveyed managers' position complies with and the number of employees directly subordinated to the manager.

In the study different level managers of medium-sized (57.1\%) and big-sized (33.3\%) companies have taken part, representing both local capital (57.1\%) and foreign capital (42.9\%) manufacturing companies; $76.2 \%$ of the surveyed manufacturing enterprise managers represent companies orientated towards the international market. $19 \%$ of the surveyed managers work for both electric gadget production and printing and 
record reproduction companies, $14.3 \%$ managers - make hardware production companies, but $38.1 \%$ of the surveyed managers - in another kind of manufacturing enterprises. In the study mostly the managers of the middle management level (57.1\%) of manufacturing companies have taken part and most of them have 13 or more employees in direct subordination $(83.3 \%)$, in its turn for more than a half of the higher level managers $(55.6 \%)$ have 6-12 employees in their subordination.

Research restrictions: the research is Case Study, therefore the obtained findings can only be related to the different level managers' opinion of eight manufacturing companies of Liepaja City and its surroundings involved in the research about the ongoing processes in the company.

\section{Results and discussion}

In order to achieve the aim of this study, firstly it was important to clarify what outcomes of the company's operation are set as primary. According to the collated outcomes in Figure 1, the product quality and defect reduction (66.7\%) and provision of the due data/ deadline accuracy (52.4\%) in the surveyed companies are the primary performance outcomes, but in its turn the issue of labour productivity increase related to them is topical only for $33.3 \%$ of the companies, in addition mostly just in the big companies (57.1\%). Due to the comparative analysis a similar situation was revealed in relation to the medium-sized manufacturing companies, where more attention is paid to the product quality $(83.3 \%)$ and execution time $(66.7 \%)$. Whereas only $25 \%$ of medium-sized company managers have marked the increase of labour productivity as the primary performance outcome in their companies (see Figure 1).

Concurrently to the applied technology, labour productivity is also affected by the chosen work organization, division of labour and specialization, employees' education and qualification, incentives or interest into work etc. (Sinicins, 2009; Karnīte, 2012).

Finding out what activities have been implemented during the last year for the sake of labour productivity increase in the manufacturing companies involved in Case Study, it has been revealed: if in medium-sized companies the attention has been paid equally to the issues of work conditions (50\%), employees' load (50\%), payment system $(50 \%)$, organizational structure $(58.3 \%)$, also technologies $(50 \%)$, then in the big companies separate measures for labour productivity growth have been noted: improvement of work conditions (85.7\%), introduction of progressive work organizational forms (71.4\%) and planning of employees' load/ working hours (57.1\%) (see Figure 2).

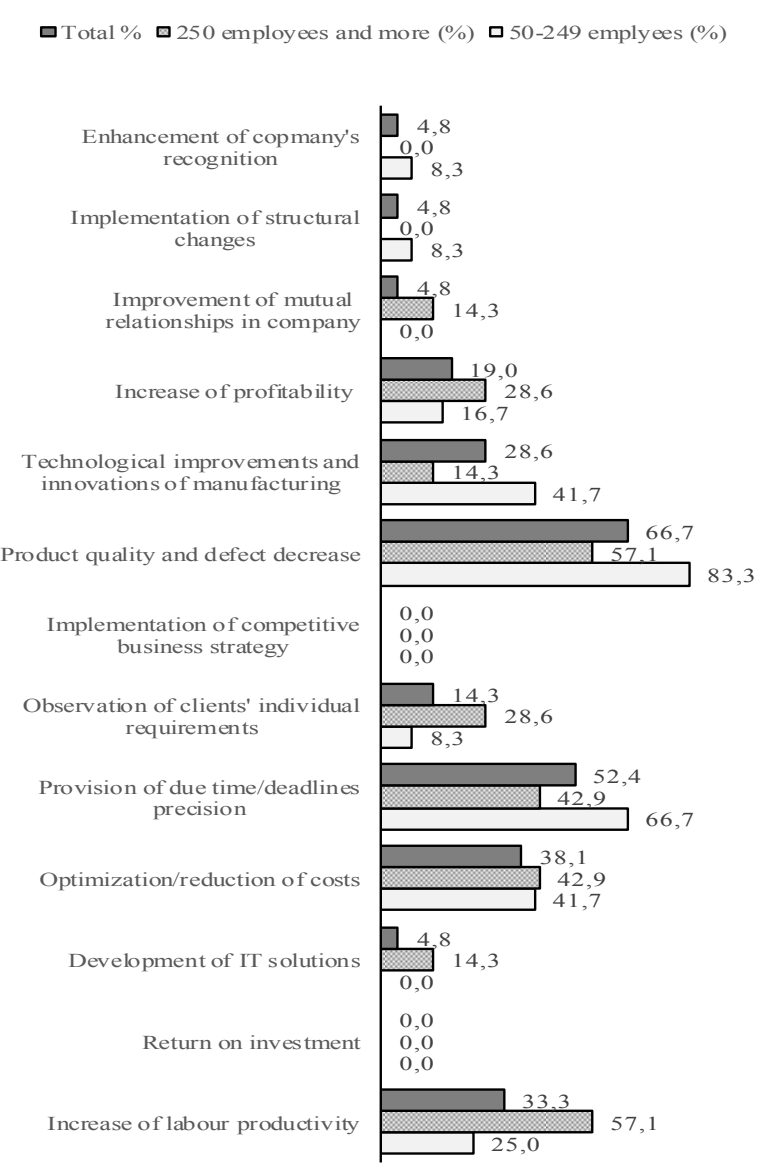

Figure 1. Primarily set performance outcomes in manufacturing enterprises of Liepaja City and its surroundings (source: authors)

The obtained outcomes in the context of labour productivity increase in general comply with Karnite's opinion that improvement of working conditions, work organization are up to the employer, whereas work intensity and quality also depend on the employee. According to Haas and Mortensen (2016), as every individual doesn't have to possess superlative technical and social skills, when building a team, it is necessary to include members with balanced skills, diversity in knowledge, views, and perspectives (Haas \& Mortensen, 2016). In this respect an interesting situation has been revealed in the collated results in Figure 2. 


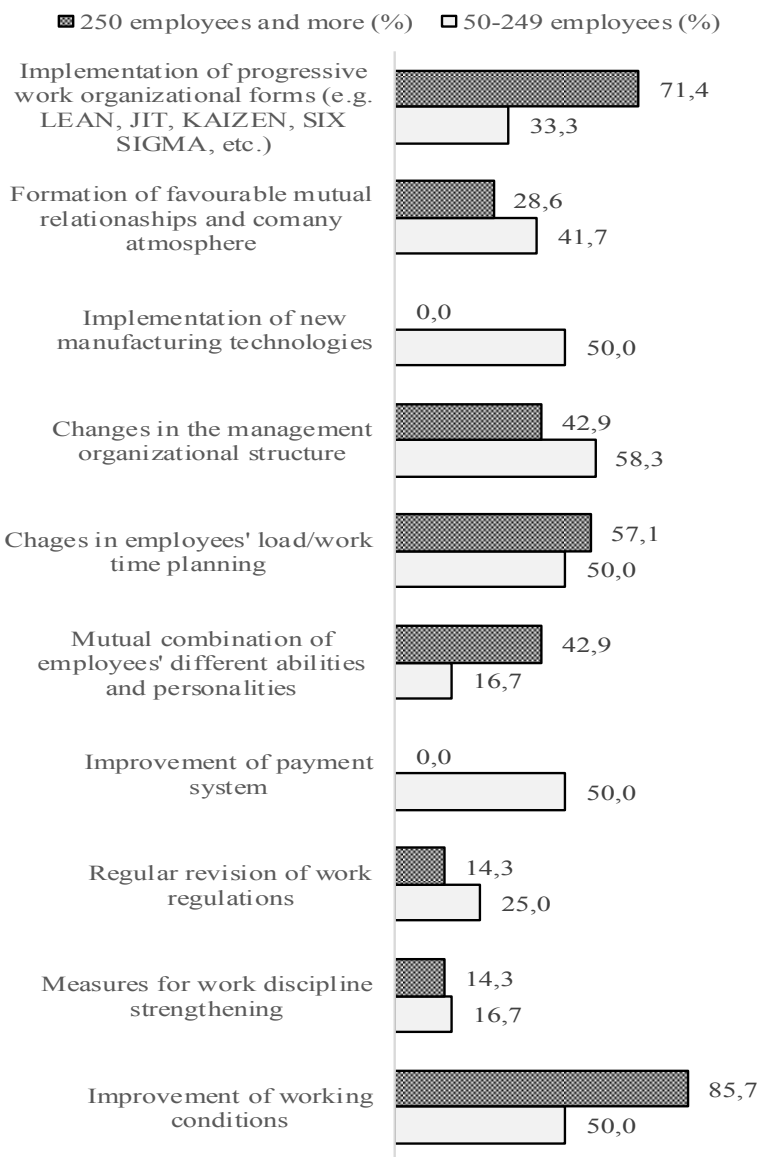

Figure 2. Implemented activities for labour productivity increase in medium-sized and big-sized manufacturing companies of Liepaja City and its surroundings during the last year (source: authors)

They prove that combination of employees' varied abilities and personalities for labour productivity increase during the last year has been noticed as more topical just in the big-sized manufacturing companies during the last year $(42.9 \%)$. The outcomes do not show that in the medium-sized manufacturing companies this issue is not topical at all. However, attention should be paid to the fact in the big-sized companies the introduction of the progressive work forms is at the top list of labour productivity increase activities, due to which it is necessary to promote the significance of the human factor - different abilities, skills, knowledge, progressive thinking when implementing and executing these work forms. Also other studies confirm that the manager's philosophy, which promotes teamwork, self-organization and responsibility, is necessary for implementation of Six Sigma quality (John, 2009) and Lean programmes in manufacturing (Colazo, 2016; Grant \& Hallam, 2016), revealing a positive association between team member's collaboration and schedule performance and labour efficiency, as well positive relation between team flexibility and product quality (Grant \& Hallam, 2016). The research carried out by Hamilton, Nickerson, and Owan (2012) also shows use of a novel panel data from a garment plant that shifted from individual piece rate to group piece rate production over three years, gaining approval that "teams with more heterogeneous worker abilities are more productive at the plant" (Hamilton et al., 2012).

Work organization includes in itself the work management system, work organizational forms, work coordination, specialization and cooperation. However, there are no certain proofs which work organizational forms are the most efficient (Karnite, 2012). In this context the surveyed managers' responses (see Table 1) show that work organization in manufacturing enterprises is mostly implemented on the horizontal environmental level, revealing the employees' independence in their duty performance (33.3\%), ability to cooperate, make joint decisions and express also their own suggestions $(28.6 \%)$ as the main characteristics. However, only $14.3 \%$ of all managers have been able to confirm that their employees cooperate being aware of each other's opinions and points of view. The data comparative analysis does not also confirm that in the medium-sized companies the employees' mutual cooperation, which is based on the employees' mutual "recognition", would be more distinct than in the bigsized companies. However, it does reveal that in the medium-sized manufacturing companies the managers' interference into the directly subordinated employees' duty performance is less observed and employees' submission of proposals is higher (see Table 1).

In its turn, work group formation with subordination to a certain manager is more distinct just in big companies. The above mentioned makes us think that in the medium-sized manufacturing companies work organization is more directed towards the upward communication and to such working environment, including creation of atmosphere, which promotes the employees' independence, thus reducing the need for a reinforced control from the direct manager's side. Such a situation - implementation differences of a teamwork-directed approach in different-sized companies can potentially be explained with the manager's power positions: the more the people, who are superior in the hierarchy of the organization's structure, think they have the rights to determine the inferior's work, control their behaviour, the bigger the power distance is, and 
therefore the relationships between employees and management are encumbered (Renge, in Dāvidsone, 2008).

On the basis of the cognitions obtained in the teamwork studies during the last 15 years, Haas and Mortensen (2016) has mentioned that even though comparing today's teams with the past, they're far more diverse, dispersed, digital, and dynamic, as well with frequent changes in membership. Nevertheless, their success still hinges on a core set of fundamentals for group collaboration. Quite a lot of studies in such active research areas as educational management, social work and medicine justify the significance of teamwork in such conditions where a certain group of people have to cooperate in order to achieve one goal and solve a particular task within the company (Weiss \& Hoegl, 2015; Dalati, Raudeliūnienè, \& Davidavičienè, 2017).

However, regardless of the company/organization's scope of operation or direction, its location, number of employees and other parameters, teams are formed and work in teams is carried out in order to achieve the company's goal and it does not matter_ "whether that goal is to improve production, increase quality, better morale, happier customers" (Harrington-MacKin, 1994) or employees satisfaction with the job. In Table 2 the collated data of the managers from Liepaja City and its surrounding manufacturing companies confirm the pursuit of a common goal by employees subordinated to a manger is common in the mediumsized companies $-75 \%$ of the medium-sized managers have pointed it out. Regarding the big companies-this can only be confirmed by $28.6 \%$ of the surveyed managers (see Table 3 ). Moreover, only $50 \%$ of the medium-sized (see Table 2) and even smaller number of the managers from big manufacturing companies (28.6\%) (see Table 3 ) have been able to confirm their directly subordinated employees' belief in teamwork. At the same time, improvement of the employees and managers' mutual relationships and each other's support (85.7\%) is more noticed in the managers' replies of big companies (see Table 3) and medium-sized companies (see Table 2). The collated data in Table 2 and 3 shows there is not a single element describing teamwork which would be totally neglected in manufacturing companies. However, creativity in problem solving and unity in the decision-making process are the aspects which are seen in the companies the least (see Table 2 and 3).

Table 1. Description of work environment in the medium-sized and big-sized manufacturing enterprises of Liepaja City and its surroundings (source: authors)

\begin{tabular}{|c|c|c|c|}
\hline & \multicolumn{3}{|c|}{ Total number of employees in the enterprise } \\
\hline & $\begin{array}{l}\text { 50-249 employ- } \\
\text { ees (\%) }\end{array}$ & $\begin{array}{c}250 \text { employees and } \\
\text { more }(\%)\end{array}$ & Total \% \\
\hline \multicolumn{4}{|l|}{ Vertical work performance } \\
\hline $\begin{array}{l}\text { Employees carry out the direct manager's in- } \\
\text { structions without expressing their opinion }\end{array}$ & 0.0 & 0.0 & 0.0 \\
\hline Employees work as they are told to do it & 0.00 & 14.3 & 4.8 \\
\hline Subordinates execute orders & 16.7 & 0.0 & 9.5 \\
\hline $\begin{array}{l}\text { Work groups are formed which are directly } \\
\text { subordinated to a certain manager }\end{array}$ & 25.0 & 71.4 & 38.1 \\
\hline Horizontal work environment & $\begin{array}{l}50-249 \text { employ- } \\
\text { ees }(\%)\end{array}$ & $\begin{array}{c}250 \text { employees and } \\
\text { more }(\%)\end{array}$ & Total \% \\
\hline $\begin{array}{l}\text { Employees mostly execute their duties without } \\
\text { the direct manager's reinforced interference }\end{array}$ & 50.0 & 14.3 & 33.3 \\
\hline $\begin{array}{l}\text { Employees cooperate knowing each other's } \\
\text { thoughts and opinions }\end{array}$ & 16.7 & 14.3 & 14.3 \\
\hline Employees cooperate and make joint decisions & 33.3 & 28.6 & 28.6 \\
\hline The subordinated submits their proposals & 41.7 & 14.3 & 28.6 \\
\hline
\end{tabular}


Table 2. Characteristics describing teamwork in medium-sized manufacturing companies of Liepaja City and its surroundings (source: authors)

\begin{tabular}{|l|c|c|c|}
\hline \multicolumn{1}{|c|}{$\begin{array}{c}\text { Is the below mentioned characteristic to manufacturing } \\
\text { company activity? }\end{array}$} & Yes & Partly & No \\
\hline In the manager's direct subordination existing employees' $:$ & $41.7 \%$ & $50.0 \%$ & $8.3 \%$ \\
\hline Accept and support to the made decisions & $58.3 \%$ & $41.7 \%$ & $0.0 \%$ \\
\hline Support to each other & $83.3 \%$ & $16.7 \%$ & $0.0 \%$ \\
\hline Responsibility for the duty performance & $50.0 \%$ & $50.0 \%$ & $0.0 \%$ \\
\hline Responsibility for the implementation of the made decisions & $100.0 \%$ & $0.0 \%$ & $0.0 \%$ \\
\hline Free expression of own opinion & $50.0 \%$ & $41.7 \%$ & $8.3 \%$ \\
\hline Involvement in the work performance assessment & $66.7 \%$ & $33.3 \%$ & $0.0 \%$ \\
\hline Involvement in decision-making & $58.3 \%$ & $41.7 \%$ & $0.0 \%$ \\
\hline Initiative in the work process & $66.7 \%$ & $33.3 \%$ & $0.0 \%$ \\
\hline Growth and development & $58.3 \%$ & $41.7 \%$ & $0.0 \%$ \\
\hline Self-discipline & $25.0 \%$ & $75.0 \%$ & $0.0 \%$ \\
\hline Creativity in problem solving & $66.7 \%$ & $33.3 \%$ & $0.0 \%$ \\
\hline Mutual trust in each other & $66.7 \%$ & $33.3 \%$ & $0.0 \%$ \\
\hline Improvement of mutual relationships & $75.0 \%$ & $25.0 \%$ & $0.0 \%$ \\
\hline Pursuit of a common goal & $16.7 \%$ & $83.3 \%$ & $0.0 \%$ \\
\hline Unity in decision-making & $50.0 \%$ & $41.7 \%$ & $8.3 \%$ \\
\hline Belief in teamwork & $66.7 \%$ & $33.3 \%$ & $0.0 \%$ \\
\hline $\begin{array}{l}\text { Improvement of employees and the direct manager's mutual } \\
\text { relationships }\end{array}$ & & \\
\hline
\end{tabular}

Table 3. Characteristics describing teamwork in big-sized manufacturing companies of Liepaja City and its surroundings (source: authors)

\begin{tabular}{|l|c|c|c|}
\hline \multicolumn{1}{|c|}{$\begin{array}{c}\text { Is the below mentioned characteristic to manufacturing } \\
\text { company activity? }\end{array}$} & \multicolumn{3}{c|}{ Yes employees and more } \\
\hline In the manager's direct subordination existing employees' $:$ & $57.1 \%$ & $42.9 \%$ & $0.0 \%$ \\
\hline Accept and support to the made decisions & $85.7 \%$ & $14.3 \%$ & $0.0 \%$ \\
\hline Support to each other & $57.1 \%$ & $42.9 \%$ & $0.0 \%$ \\
\hline Responsibility for the duty performance & $28.6 \%$ & $71.4 \%$ & $0.0 \%$ \\
\hline Responsibility for the implementation of the made decisions & $85.7 \%$ & $0.0 \%$ & $14.3 \%$ \\
\hline Free expression of own opinion & $71.4 \%$ & $28.6 \%$ & $0.0 \%$ \\
\hline Involvement in the work performance assessment & $71.4 \%$ & $28.6 \%$ & $0.0 \%$ \\
\hline Involvement in decision-making & $42.9 \%$ & $42.9 \%$ & $14.3 \%$ \\
\hline Initiative in the work process & $71.4 \%$ & $28.6 \%$ & $0.0 \%$ \\
\hline Growth and development & $42.9 \%$ & $42.9 \%$ & $14.3 \%$ \\
\hline Self-discipline & $42.9 \%$ & $42.9 \%$ & $14.3 \%$ \\
\hline Creativity in problem solving & $42.9 \%$ & $57.1 \%$ & $0.0 \%$ \\
\hline Mutual trust in each other & $71.4 \%$ & $28.6 \%$ & $0.0 \%$ \\
\hline Improvement of mutual relationships & $28.6 \%$ & $71.4 \%$ & $0.0 \%$ \\
\hline Pursuit of a common goal & $28.6 \%$ & $57.1 \%$ & $14.3 \%$ \\
\hline Unity in decision-making & $28.6 \%$ & $71.4 \%$ & $0.0 \%$ \\
\hline Belief in teamwork & $85.7 \%$ & $0.0 \%$ & $14.3 \%$ \\
\hline $\begin{array}{l}\text { Improvement of employees and the direct manager's mutual } \\
\text { relationships }\end{array}$ & & & \\
\hline
\end{tabular}


The outcomes of the comparative analysis also reveal that in the medium-sized companies the directly subordinated employees' responsibility for duty performance (83.3\%) and decision implementation $(50 \%)$ are more distinct (see Table 2), whereas the employees' involvement in the decision-making process and evaluation of outcomes $(71.4 \%)$ are more distinct in the big companies (see Table 3). The latter is confirmed by the managers' replies collated in Tables 4 and 5 to the question "Which elements describing teamwork affect the work outcomes managed by you as the manager?" As it can be seen in Tables 3 and 5 , all surveyed managers from the big companies have pointed to the directly subordinated employees' skills to make joint decisions.

Within the European-wide research carried out by Bikfalvi, Jäger, and Gunter (2014) an overall approval for teamwork implementation in manufacturing enterprises has been obtained. However, its rates vary significantly by country, firm size and, to a lesser extent, sector of the company's activity.

Table 4. Managers' work performance influential elements of medium-sized companies in Liepaja City and its surroundings (source: authors)

\begin{tabular}{|l|c|c|c|}
\hline \multicolumn{1}{|c|}{ Work performance managed by you depends on: } & Yes & Partly & No \\
\hline The direct subordination existing employees' mutual trust & $66.7 \%$ & $33.3 \%$ & $0.0 \%$ \\
\hline The manager's decision-making & $50.0 \%$ & $50.0 \%$ & $0.0 \%$ \\
\hline $\begin{array}{l}\text { The direct subordination existing employees' skills to make } \\
\text { joint decisions }\end{array}$ & $66.7 \%$ & $25.0 \%$ & $8.3 \%$ \\
\hline Individual employees' specialization & $75.0 \%$ & $16.7 \%$ & $8.3 \%$ \\
\hline $\begin{array}{l}\text { Precise division of functions and work formulation for the par- } \\
\text { ticular employee }\end{array}$ & $91.7 \%$ & $8.3 \%$ & $0.0 \%$ \\
\hline $\begin{array}{l}\text { Precisely implemented in your direct subordination existing } \\
\text { employees' work performance control functions }\end{array}$ & $58.3 \%$ & $33.3 \%$ & $8.3 \%$ \\
\hline Mutual employees' communications & $83.3 \%$ & $16.7 \%$ & $0.0 \%$ \\
\hline $\begin{array}{l}\text { United work team operations under your guidance or perfor- } \\
\text { mance of the given tasks autonomously. }\end{array}$ & $50.0 \%$ & $33.3 \%$ & $16.7 \%$ \\
\hline
\end{tabular}

Table 5. Managers' work performance influential elements of big-sized companies in Liepaja City and its surroundings (source: authors)

\begin{tabular}{|l|c|c|c|}
\hline \multicolumn{1}{|c|}{ Work performance managed by you depends on: } & Yes & Partly & No \\
\hline The direct subordination existing employees' mutual trust & $57.1 \%$ & $42.9 \%$ & $0.0 \%$ \\
\hline The manager's decision-making & $42.9 \%$ & $57.1 \%$ & $0.0 \%$ \\
\hline $\begin{array}{l}\text { The direct subordination existing employees' skills to make } \\
\text { joint decisions }\end{array}$ & $100.0 \%$ & $0.0 \%$ & $0.0 \%$ \\
\hline Individual employees' specialization & $71.4 \%$ & $28.6 \%$ & $0.0 \%$ \\
\hline $\begin{array}{l}\text { Precise division of functions and work formulation for the } \\
\text { particular employee }\end{array}$ & $85.7 \%$ & $14.3 \%$ & $0.0 \%$ \\
\hline $\begin{array}{l}\text { Precisely implemented in your direct subordination existing } \\
\text { employees' work performance control functions }\end{array}$ & $71.4 \%$ & $28.6 \%$ & $0.0 \%$ \\
\hline Mutual employees' communications & $71.4 \%$ & $28.6 \%$ & $0.0 \%$ \\
\hline $\begin{array}{l}\text { United work team operations under your guidance or perfor- } \\
\text { mance of the given tasks autonomously. }\end{array}$ & $42.9 \%$ & $57.1 \%$ & $0.0 \%$ \\
\hline
\end{tabular}


Even though the outcomes of Study Case show that in the manufacturing company activity in general the approach based on teamwork comes into sight, similarly to Bikfalvi's et al. (2014) research outcomes, also in this case different situations can be observed in medium-sized and bigsized manufacturing companies.

\section{Conclusions}

Different research aspects on teamwork performance outcomes in companies confirm teamwork relation to such company performance outcomes as a competitive business strategy, quality increase and defect decrease, time economy, cost savings, innovation and satisfaction with work achievement in companies. Thus application of the approach based on teamwork as a tool in business management, today offer the company managers diversity in terms of the alternative outcomes achievable by the company and choice of priorities.

In the research it is found out that management of manufacturing companies in Liepaja and its surroundings set as a priority in company work the product quality, due data precision and optimization of costs. Nevertheless, at the same time company managers want to achieve in their company the employees' bigger awareness of their role and more active involvement in team-work. Outcomes of the research reveal that from the managers' point of view labour productivity basically depends on the human resource factor. Outcomes of management work are mostly affected by a precise division of functions and work formulation for the particular employee, in direct subordination existing employees' mutual communication and skill to make joint decisions.

\section{Disclosure statement}

Authors don't have any competing financial, professional, or personal interests from other parties.

\section{References}

Barets, R. (2008). Formation of a value-orientated organization. Rīga: Society "Domas spēks".

Belbins, R. M. (2009). Jaunās organizācijas/New organizations. Rīga: Business Information Service.

Bikfalvi, A. (2011). Teamwork in production: implementation, its determinants, and estimates for German manufacturing. Human Factors and Ergonomics in Manufacturing and Service Industries, 21(3), 244-259. https://doi.org/10.1002/hfm.20230
Bikfalvi, A., Jäger, A., \& Gunter, L. (2014). The incidence and diffusion of teamwork in manufacturing - evidences from a pan-European survey. Journal of Organizational Change Management, 27(2), 206-231. https://doi.org/10.1108/JOCM-04-2013-0052

Boning, B., Ichniowski, C., \& Shaw, K. (2007). Opportunity counts: teams and the effectiveness of production incentives. Journal of Labor Economics, 25(4), 613-650. https://doi.org/10.1086/519539

Colazo, J. (2016, January). Team network evolution while undergoing a lean transformation: a missing success indicator?. 49th Annual Hawaii International Conference on System Sciences (pp. 473-479). Island of KauaiKoloa, USA. https://doi.org/10.1109/HICSS.2016.65

Dalati, S., Raudeliūnienė, J., \& Davidavičienè, V. (2017). Sustainable leadership, organizational trust on job satisfaction: empirical evidence from higher education institutions in Syria. Business, Management and Education, 15(1), 14-27. https://doi.org/10.3846/bme.2017.360

Dāvidsone, G. (2008). Efficiency model of organizations. Jelgava: Jelgava Printing House, O.D.A. Ltd.

Dumaine, B. (1989). What the leaders of tomorrow see. Fortune, 120(1), 48-62.

Faisal, A. M., Abdelghafour, A. Z., \& Sukina, A. S. (2012). The implementation of teamwork in Jordan. European Journal of Economics, Finance and Administrative Sciences, (45), 107-114.

Flores-Fillol, R., Iranzo, S., \& Mane, F. (2017). Teamwork and delegation of decisions within the firm. International Journal of Industrial Organization, 52, 1-29. https://doi.org/10.1016/j.ijindorg.2017.01.008

Grant, K. P., \& Hallam, C. R. A. (2016). Team performance in a lean manufacturing operation: it takes the will and a way to succeed. International Journal of Technology Management, 70(2), 177-192. https://doi.org/10.1504/IJTM.2016.075161

Haas, M., \& Mortensen, M. (2016). The secrets of great teamwork. Harvard Business Review. Retrieved from https://hbr.org/2016/06/thesecretsofgreatteamwork

Hamilton, B. H.; Nickerson, J. A.; Owan, H. 2012. Diversity and productivity in production teams. In A. Bryson (Ed.), Advances in the economic analysis of participatory and labour-managed firms, 13, 99-138. Retrieved from http://www.emeraldinsight.com/doi/ pdfplus/10.1108/S0885-3339\%282012\%29000001 3009

Hamilton, B., Nickerson, J., \& Owan, H. (2003). Team incentives and worker heterogeneity: an empirical analysis of the impact of teams on productivity and participation. Journal of Political Economy, 111(8), 465-497. https://doi.org/10.1086/374182

Harrington-MacKin, D. (1994). The team building tool kit. New York: Amacom.

Harvard Business Review on. (2008a). Assessment of company performance. System of balanced indices - indices of work efficiency. Rīga: Business Information Centre.

Harvard Business Review on. (2008b). Assessment of company performance. How a team can become outstanding applying the right indices. Rīga: Business Information Centre.

Herman, S. M., \& Herman, M. O. (1989). Special teams, properly used, can create effective solutions. Personnel Administrator October, 90-92.

Hoerr, J. (1987). Getting man and machine to live happily ever after. Business Week, April 20, 61-62. 
John, K. J. (2009). Agile model to support quick changes in roduct lines. IDIMT-2009: System and humans, a complex relationship. Book Series: Schriftenreihe Informatik, 29, 57-65.

Karnīte, R. (2012). Labour productivity influential factors and productivity increase possibilities. Rīga: Centre of Economic Forecasts. Ltd.

Katzenbach, J. R., \& Smith, D. K. (2015). The wisdom of teams: creating the high-performance organization. Boston, Massachusetts: Harvard Business Review Press.

Ķeniņš Kings, G., Krūmiṇš, J., Spīča, I., Bargā, I., Veikmane, V., \& Rudzītis, G. (2002). Hand in hand. Faster, higher, stronger. Rīga: Publishing House Business Partners.

Lawler, E. E. (1986). High involvement management. San Francisko: Jossey-Bass.

Maginn, D. M. (1994). Effective teamwork. USA: McGrowHill.

Mayo, E. (1933). The human problems of an industrial civilization. Cambridge, Mass: Harward University.

Merkevičius, J., Davidavičienė V., Raudeliūnienė J., \& Buleca, J. (2015). Virtual organization: specifics of creation of personnel management system. E\&M Economics and Management Liberec, 18(4), 200-211. https://doi.org/10.15240/tul/001/2015-4-014

National Industrial Policy Guidelines 2012-2020. The Cabinet of Ministers Order No 282 on June 28, 2013. Retrieved from http://polsis.mk.gov.lv/documents/4391
Palčic, I., Buchmeister, B., \& Polajnar, A. (2010). Analysis of innovation concepts in Slovenian manufacturing companies. Joumal of Mechanical Engineering, 56(12), 803-810.

Raudeliūnienè, J., \& Meidute, I. (2014). Analysis of factors motivating human resources in public sector. Procedia - Social and Behavioral. The 2nd International Scientific conference "Contemporary Issues in Business, Management and Education 2013”, 110, 719-726. Amsterdam: Elsevier Science Ltd.

Sheridan, J. H. (1990). America's best plants. Industry Week October, 27-44.

Siṇicins, M. (2009). Ekonomika. Rīga: Publishing House RaKa.

Weiss, M., \& Hoegl, M. (2015). The history of teamwork's societal diffusion: a multi-method review. Small Group Research, 46(6), 589-622. https://doi.org/10.1177/1046496415602778

West, M. (2004). Motivate teams, maximize success. San Francisco: Chronicle books LLC.

West, M. (2012). Effective teamwork: practical lessons from organizational research (3rd Ed.). Wiley-Blackwell.

Zvirbule-Bērziņa, A., Mihejeva, L., \& Auziņa, A. (2004). Basic principles of planning and manufacturing process organization. Rīga: Publishing House of Business Higher Educational Establishment "Turība". 